\title{
Information and communication technologies for knowledge management in academic libraries in Nigeria and South Africa
}

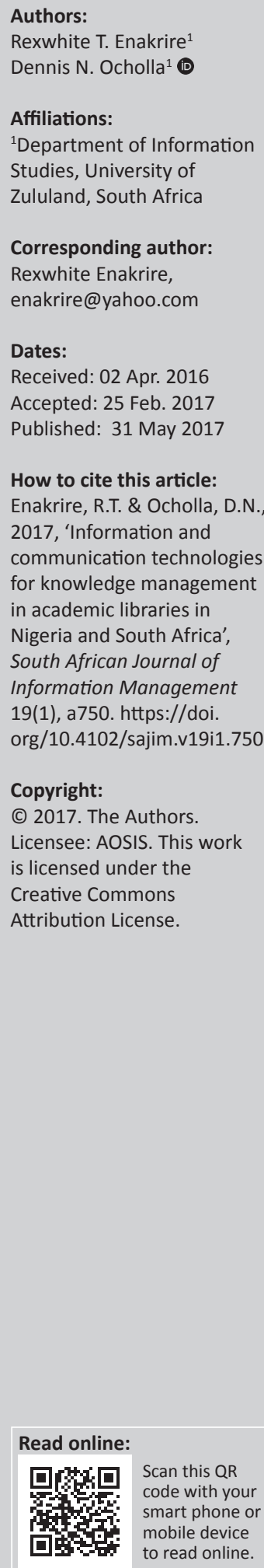

Background: Presently, libraries, especially academic libraries, have increasingly used information and communication technologies (ICTs) to automate their core functions in order to implement efficient and effective library operations and services. This now requires library and information professionals as knowledge workers to intensify managing both explicit and tacit knowledge for the organisational growth of the libraries.

Objectives: The objective of this study was to investigate the use of ICT facilities that support knowledge management (KM) in academic libraries in Nigeria and South Africa.

Methods: Both quantitative through survey and structured questionnaires and qualitative by content analysis and interview research methodologies were applied in the initial study. The qualitative approach of content analysis was applied to literature review, and key informants were also interviewed. One hundred and thirty-two professional librarians and six key informants across the sampled academic libraries in the two countries were targeted for information. The study sampled only six academic libraries, three in each country, which renders generalisation difficult. This article largely focuses on quantitative aspects of the study in the reported findings.

Results: Availability and accessibility of ICTs for KM among the sampled libraries were not uniform, even within one country. Infrastructural support has affected some of the university libraries to a great extent. The knowledge and skills for using ICT for KM were largely adequate, but varied within the libraries and librarians as well. The challenges facing the libraries border on inadequate infrastructure and professional staff, but irrespective of the challenges faced, libraries have devised strategies for coping and rendering services. The study has provided new information relating to the use of ICT facilities and services for KM in academic libraries that calls for rigorous continuing education for re-skilling the librarians. The changing user behaviour also calls for major attention. Government support for academic libraries with policy and funding is still crucial.

Conclusion and recommendation: The study concludes that because ICTs have had robust histories as used to support information services, both staff and students' information needs to be met in a variety of ways in academic libraries. This would help to foster and improve the understanding of how librarians manage the organisation in present-day library operations. We recommend that staff development be intensified to enable how librarians could cope with changes and new technologies for modern information services being encouraged and acquired. This article provides a unique long-term survey on the use of ICT facilities and services, strategy and structure in an academic and/or university library services.

\section{Introduction and conceptual background}

The purpose of university libraries is to support research, teaching and learning in universities. Information and communication technologies (ICTs) play a crucial role in the development of academic libraries. ICT has been defined as a diverse set of technological tools and resources that can be used to communicate, create, disseminate, store and manage information and knowledge in the global context (Blurton 1999:46). Also, UNESCO (2002) acknowledges that ICTs consist of a range of technologies that are applied in the process of collecting, storing, editing, retrieving and transferring information in various forms. They comprise both old and new technologies such as telecommunication technologies comprising telephony, cable, satellite, television, radio, computer-mediated conferencing and video conferencing; digital technologies such as computers, information networks, Internet, World Wide Web, intranets and extranets; and software applications (Anunobi et al. 2011; Ofori-Dwumfuo \& Kommey 2013:92). 
Libraries, especially academic libraries, are increasingly using ICTs to access digitalised information. This became feasible through automated core functions of library operations and services. The efficiency and effectiveness of the core functions result in implementation of laid down policy that guides the academic library. Increasingly, library and information professionals are now being referred to as 'knowledge managers' and libraries and information centres as 'knowledge centres' (Rowley 2003) as they handle both explicit and tacit knowledge. Explicit knowledge is the human knowledge that has been captured orally (e.g. in song), in writing (documents or books), and in movies and images, among others (Dalkir 2011:9). This type of knowledge is easy to interpret, represent and share among individuals for effective application (Evangelista et al. 2010). Knowledge that is tied to the senses (e.g. tactile experiences, movement, skills, intuition and unarticulated mental models) or implicit rules of thumb can be defined as 'tacit' knowledge (Nonaka \& Krogh 2009). Tacit knowledge is rooted in action, procedures, routines, commitment, ideals, values and emotions (Nonaka, Umemoto \& Senoo 1996). Tacit knowledge is difficult to express, represent and communicate. It can be described as personal knowledge that is embedded within the individual, representing his or her experiences and involving intangible factors such as personal beliefs, perspectives, instincts and values (Nonaka 1994; Nonaka, Ichijo \& Von Krogh 2004). We assume that when the differences between explicit and tacit knowledge are known, it is possible for an academic library and librarians to strategize its full exploitation. The principal challenge faced in handling tacit knowledge is still that of translating the knowledge into communicable form (Minonne 2007).

Knowledge management (KM) is largely viewed to be the management of explicit and tacit knowledge (Skyrme 1997) whose components include people, processes and technology, all of which occur in the library environment. KM has benefited from ICT application, as libraries have largely managed explicit knowledge for centuries. Despite its historical application in libraries, KM is still viewed to be an emerging discipline drawn from a broad range of established disciplines such as organisational learning, networking, intellectual capital, social construction, communities of practice and social interaction (Beesley \& Cooper 2008).

The relevance of ICTs for KM cannot be downplayed in today's knowledge economy. The essence of this assertion is that, prior to the advent of ICTs, the management of knowledge, either the explicit or the tacit, has been hampered by several reasons: (1) the slow nature of the acquisition and processing, (2) storage and retrieval mechanism used, (3) librarians fatigue as a result of many volume of work, and (4) unwillingness or drive because of lack of motivation by the organisation. Therefore, for the utilisation of ICTs for KM to be actualised, strategies of management techniques must be in place in order to foster knowledge creation or acquisition, processing, repackaging, storage, retrieval and dissemination in academic libraries. This would enforce the adoption and application of ICTs used in the library organisation. According to Martin (2015), ICTs improve work performance and foster innovation among employees in organisations. Other reasons for ICTs in libraries, as raised by Bhardwaj and Walia (2012), Online Computer Library Center (2002), Dafiaghor (2012) and Ridwan (2015), include the following:

- Indexed and abstracted sources of information, and theses and dissertations that are available in web portals and institutional repositories can be easily accessed and retrieved via library websites because of ICTs (Bhardwaj \& Walia 2012).

- The influx of large volumes of information and knowledge is easily managed in different databases by librarians with ICT tools in libraries (Bhardwaj \& Walia 2012).

- Users of libraries can easily access and use library resources with the aid of Online Catalogue of Library of Congress or Online Computer Library Center (OCLC) without necessarily physically visiting the library building (Bhardwaj \& Walia 2012; OCLC 2002).

- Generally, library and information operations and services have profoundly improved since the introduction of ICTs in libraries (Dafiaghor 2012).

- Library professionals have changed from custodians of information and knowledge to facilitators of library resources and services through organised workshops, seminars, and current awareness or display activities (Ridwan 2015).

- Librarians have adopted new techniques, knowledge and skills of managing information and knowledge through the use of the latest ICT tools (Ridwan 2015).

- Presently, librarians have improved themselves through training and re-training in different programmes, and research collaboration among colleagues (Ridwan 2015).

The rationale of the study is that current trends of library operations and services require the use of ICTs to facilitate meeting users' information needs. As a result of influx of information and knowledge in diverse context and area of specialisation, ICTs are essential for proper management functions of the organisation. The authors considered the technology acceptance model (TAM) developed by Davis (1989) appropriate for this article for the following reasons: (1) TAM addressed the principles and challenges that relate to the access and the use of ICT; (2) TAM has been validated through several testing of the theory, as it predicts phenomenon (Taiwo \& Downe 2013; Venkatesh et al. 2008; Venkatesh, Thong \& Xu 2012); (3) TAM accurately predicts users' intentions with regard to the use of technologies (AlQeisi 2009:1); (4) TAM was chosen with the intention of the intervening variables of 'use and perceived ease of use' (Davis 1989). The theory was meant to address specifically the factors that affect or influence the acceptance and use of computer technology or ICT facilities in organisations. The TAM theory has two unique variables of usefulness and perceived ease of use which has attracted a lot of attention by both proponents and opponents of the model. The rationale behind adopting this theory in this research article was that it fundamentally looks at how an individual found 
systems to be useful and perceived ease of use in their operations in the organisations. Many studies use TAM for understanding how ICT is perceived and used. For example, studies by Lee, Kozar and Larsen (2003), Ramayah (2006), Venkatesh and Davis (2000), Venkatesh (2000), Venkatesh et al. (2003), Venkatesh and Bala (2008), Davis, Bagozzi and Warshaw (1989), King and He (2006), just to mention but a few, have demonstrated the relationship of attitude and intention to use and not to use systems. Most of these studies also agree that intervening variables reflect flexible, proven, valid and reliable measures that predict the acceptance to use new technologies by end users in this contemporary knowledge economy. We have found other recent studies (e.g. Fari 2015) that represent arguments by TAM critics quite useful, particularly in confirming that TAM is still useful for application in related studies such as this one.

\section{Purpose of the study}

This study's fundamental focus was on how and to what extent ICT facilities support KM in selected university libraries in Nigeria and South Africa. In this article, we focused on the following research questions:

- What are the available ICT facilities used to support KM in academic libraries in Nigeria and South Africa?

- To what extent are librarians utilising ICTs to support KM in academic libraries in Nigeria and South Africa?

- What are the challenges faced in the use of ICTs for the support of KM in academic libraries in Nigeria and South Africa?

\section{Methodology}

The quantitative (survey) and qualitative (interpretive and content analysis) research methods were employed in this article. The research design employed for this research article was the survey, interpretive and content analysis. The population largely covered professional librarians across six sampled university libraries in Nigeria and South Africa. The non-probability sampling, specifically purposive sampling, enabled the selection of three university libraries from the southern part of Nigeria, namely the University of Ibadan (UI), Federal University of Technology (FUT) and Delta State University (DSU), and three university libraries from KwaZulu-Natal Province in South Africa: the University of KwaZulu-Natal (UKZN), University of Zululand (UZ) and Durban University of Technology (DUT). In the six sampled university libraries above, 171 professional librarians were targeted for the study. This was done through selection of accidental and purposive sampling. The selection was based on the available librarian working in each of the university chosen for the study. Therefore, 38 were obtained from UI library, 18 were recorded in FUT library, 44 from DSU library, 12 from the UZ library, 33 made up of UKZN library and 26 from DUT. These made up the 171 professional librarians sampled in the six university libraries in both countries. The UI and UKZN libraries were selected based on the fact that they are well established, as well as the oldest universities in the two respective countries. The FUT and DUT libraries were selected because they both are technology-based libraries that are vocational and professional oriented, whereas the DSU and UZ libraries were included in the study because of their rural location and proximity to the researchers.

The structured questionnaires were administered to the professional librarians across the sampled university libraries in Nigeria and South Africa. The administration of the questionnaire to the respondent across the six university libraries was between July and August, 2013, and it lasted for 3-4 weeks. Six key informants working in the university libraries in the two countries were also interviewed. The responses obtained were captured and reported in the findings of this article. Observation was used to gather data regarding the university libraries' environment, physical structure and location, office space (conduciveness), availability and accessibility of computers and other ICT tools, collections (print and electronic resources), shelving space, size and lighting in the office, and attitude of staff towards their work. Of the 171 questionnaires administered, 132 (77.2\%) were returned. The 132 (77.2\%) returned questionnaires consisted of 77 respondents from university libraries in Nigeria and 55 respondents from university libraries in South Africa. The 132 copies of questionnaires returned were analysed using descriptive statistics. The profiles of the respondents are presented in Table 1.

\section{Results and discussion of findings}

The results of this article are presented in the following sections.

\section{What are the available information and communication technology facilities for the support of knowledge management in the selected academic libraries in Nigeria and South Africa?}

The question on the available ICT facilities for KM was done in order to obtain clear understanding of each of the item in the variables (availability, with emphasis to accessibility and effectiveness of ICT facilities). Result of the available ICT facilities is represented in Table 2. It was found that ICT tools varied from library to library. The most available ICT tools across the sampled university libraries in the two countries appeared to be computers, CD-ROMs, scanners, projectors, telephones, printers and monitors. It was noted, through inter-country comparison, that the most resourced libraries were FUT Library, Akure (FUTA) and UZ. UI and UKZN were almost equal in the availability of ICT resources or tools. Findings from the interviews and observation concurred with those of the questionnaire, with the addition of ICT tools such as microphones, CCTV and video cameras, $\mathrm{Wi}-\mathrm{Fi}$, e-catalogues, databases and telephones. However, these were not mentioned in the questionnaire. It was not possible to ascertain whether all the facilities mentioned and 
TABLE 1: The profile of the respondents.

\begin{tabular}{|c|c|c|c|c|c|c|c|c|c|c|c|c|c|c|}
\hline \multirow[t]{3}{*}{ Variables } & \multicolumn{14}{|c|}{ Demographic data across university libraries (Nigeria and South Africa) } \\
\hline & \multicolumn{2}{|c|}{ UI library } & \multicolumn{2}{|c|}{ FUT library } & \multicolumn{2}{|c|}{ DSU library } & \multicolumn{2}{|c|}{ UZ library } & \multicolumn{2}{|c|}{ UKZN library } & \multicolumn{2}{|c|}{ DUT library } & \multicolumn{2}{|c|}{ Total } \\
\hline & $F$ & $\%$ & $F$ & $\%$ & $F$ & $\%$ & $F$ & $\%$ & $\boldsymbol{F}$ & $\%$ & $F$ & $\%$ & $F$ & $\%$ \\
\hline \multicolumn{15}{|l|}{ Gender } \\
\hline Male & 17 & 26.2 & 10 & 15.4 & 14 & 21.5 & 2 & 3.1 & 13 & 20.0 & 9 & 13.8 & 65 & 49.2 \\
\hline Female & 12 & 17.9 & 6 & 9.0 & 18 & 26.9 & 7 & 10.4 & 15 & 22.4 & 9 & 13.4 & 67 & 50.8 \\
\hline Total & 29 & 44.1 & 16 & 24.4 & 32 & 58.4 & 9 & 13.5 & 28 & 42.4 & 18 & 37.2 & 132 & 100 \\
\hline \multicolumn{15}{|l|}{ Age } \\
\hline $20-29$ years & 2 & 6.9 & 0 & 0.0 & 2 & 6.3 & 1 & 11.1 & 1 & 3.6 & 1 & 5.6 & 7 & 5.3 \\
\hline $30-39$ years & 14 & 48.3 & 3 & 18.8 & 12 & 37.5 & 1 & 11.1 & 8 & 28.6 & 8 & 44.4 & 46 & 34.8 \\
\hline $40-49$ years & 11 & 37.9 & 9 & 56.3 & 12 & 37.5 & 3 & 33.3 & 13 & 46.4 & 6 & 33.3 & 54 & 40.9 \\
\hline 50-59 years & 2 & 6.9 & 3 & 18.8 & 6 & 18.8 & 4 & 44.4 & 5 & 17.9 & 2 & 11.1 & 22 & 16.7 \\
\hline 60 years and above & 0 & 0.0 & 1 & 6.3 & 0 & 0.0 & 0 & 0.0 & 1 & 3.6 & 1 & 5.6 & 3 & 2.3 \\
\hline Total & 29 & 100 & 16 & 100 & 32 & 100 & 9 & 100 & 28 & 100 & 18 & 100 & 132 & 100 \\
\hline \multicolumn{15}{|l|}{ Qualifications } \\
\hline Honours degree & 0 & 0.0 & 0 & 0.0 & 0 & 0.0 & 2 & 13.3 & 9 & 60.0 & 4 & 26.7 & 15 & 11.4 \\
\hline Master's degree & 18 & 28.1 & 9 & 14.1 & 15 & 23.4 & 2 & 3.1 & 11 & 17.2 & 9 & 14.1 & 64 & 48.5 \\
\hline $\mathrm{PhD}$ degree & 3 & 33.3 & 1 & 11.1 & 4 & 44.4 & 0 & 0.0 & 1 & 11.1 & 0 & 0.0 & 9 & 6.8 \\
\hline Total & 29 & 79.6 & 16 & 38.8 & 32 & 97.3 & 9 & 27.8 & 28 & 104 & 18 & 52.2 & 132 & 100 \\
\hline \multicolumn{15}{|l|}{ Position or rank } \\
\hline University librarian & 0 & 0.0 & 1 & 100 & 0 & 0.0 & 0 & 0.0 & 0 & 0.0 & 0 & 0.0 & 1 & 100 \\
\hline Dep. Uni. librarian & 1 & 50.0 & 1 & 50.0 & 0 & 0.0 & 0 & 0.0 & 0 & 0.0 & 0 & 0.0 & 2 & 100 \\
\hline Principal librarian & 3 & 33.3 & 2 & 22.2 & 1 & 11.1 & 0 & 0.0 & 3 & 33.3 & 0 & 0.0 & 9 & 100 \\
\hline Senior librarian & 7 & 17.5 & 0 & 0.0 & 2 & 5.0 & 2 & 5.0 & 18 & 45.0 & 11 & 27.5 & 40 & 100 \\
\hline Librarian I & 2 & 22.2 & 3 & 33.3 & 3 & 33.3 & 0 & 0.0 & 0 & 0.0 & 1 & 11.1 & 9 & 100 \\
\hline Librarian II & 5 & 26.3 & 3 & 15.8 & 7 & 36.8 & 2 & 10.5 & 1 & 5.3 & 1 & 5.3 & 19 & 100 \\
\hline Assistant librarian & 1 & 9.1 & 0 & 0.0 & 7 & 63.6 & 1 & 9.1 & 2 & 18.2 & 0 & 0.0 & 11 & 100 \\
\hline Chief library officer & 0 & 0.0 & 1 & 33.3 & 1 & 33.3 & 0 & 0.0 & 0 & 0.0 & 1 & 33.3 & 3 & 100 \\
\hline Senior library officer & 1 & 16.7 & 2 & 33.3 & 1 & 16.7 & 2 & 33.3 & 0 & 0.0 & 0 & 0.0 & 6 & 100 \\
\hline Principal library officer & 0 & 0.0 & 0 & 0.0 & 0 & 0.0 & 0 & 0.0 & 0 & 0.0 & 0 & 0.0 & 0 & 0.0 \\
\hline Principal library assistant & 0 & 0.0 & 0 & 0.0 & 0 & 0.0 & 1 & 100 & 0 & 0.0 & 0 & 0.0 & 1 & 100 \\
\hline Total & 29 & - & 16 & - & 32 & - & 9 & - & 28 & - & 18 & - & 132 & 100 \\
\hline \multicolumn{15}{|l|}{ Work experience } \\
\hline $1-5$ years & 11 & 35.5 & 1 & 3.2 & 4 & 12.9 & 4 & 12.9 & 5 & 16.1 & 6 & 19.4 & 31 & 100 \\
\hline $6-10$ years & 4 & 10.8 & 6 & 16.2 & 11 & 29.7 & 0 & 0.0 & 9 & 24.3 & 7 & 18.9 & 37 & 100 \\
\hline $11-15$ years & 10 & 45.5 & 4 & 18.2 & 2 & 9.1 & 0 & 0.0 & 3 & 13.6 & 3 & 13.6 & 22 & 100 \\
\hline $16-20$ years & 2 & 9.5 & 2 & 9.5 & 9 & 42.9 & 1 & 4.8 & 6 & 28.6 & 1 & 4.8 & 21 & 100 \\
\hline $21-25$ years & 2 & 18.2 & 2 & 18.2 & 4 & 36.4 & 1 & 9.1 & 2 & 18.2 & 0 & 0.0 & 11 & 100 \\
\hline 26 years and above & 0 & 0.0 & 1 & 10.0 & 2 & 20.0 & 3 & 30.0 & 3 & 30.0 & 1 & 10.0 & 10 & 100 \\
\hline Total & 29 & - & 16 & - & 32 & - & 9 & - & 28 & - & 18 & - & 132 & 100 \\
\hline
\end{tabular}

UI, University of Ibadan; FUT, Federal University of Technology; DSU, Delta State University; UZ, University of Zululand; UKZN, University of KwaZulu-Natal; DUT, Durban University of Technology.

TABLE 2: Availability of information and communication technology tools for the support of knowledge management (\%).

\begin{tabular}{llllllll}
$\begin{array}{l}\text { Information and } \\
\text { communication } \\
\text { technology tools }\end{array}$ & UI & FUT & DSU & UZ & UKZN & DUT & Ave \% \\
\hline Computer & 97 & 100 & 97 & 100 & 100 & 100 & 100 \\
CD-ROM & 97 & 100 & 75 & 78 & 93 & 94 & 88.3 \\
Multi-media & 97 & 94 & 56 & 100 & 93 & 100 & 97.7 \\
Projector & 93 & 100 & 53 & 100 & 82 & 100 & 94 \\
Scanner & 97 & 100 & 84 & 89 & 96 & 100 & 95 \\
Modem & 83 & 88 & 75 & 89 & 61 & 61 & 70.3 \\
Telephones & 93 & 75 & 75 & 100 & 96 & 94 & 96.7 \\
Printer & 97 & 100 & 91 & 100 & 96 & 89 & 95 \\
Monitor & 97 & 100 & 94 & 100 & 89 & 100 & 96.3 \\
Smart board & 72 & 63 & 38 & 56 & 39 & 44 & 46.3 \\
\hline
\end{tabular}

UI, University of Ibadan; FUT, Federal University of Technology; DSU, Delta State University UZ, University of Zululand; UKZN, University of KwaZulu-Natal; DUT, Durban University of Technology; Ave, Average. observed were in good working order. However, it was noted that the computers that the librarians use, were functioning. Another clear indication of a tool that was working in the libraries was the online public access catalogue (OPAC), which is used to retrieve information resources across all fields of study.

It was noted that some of the computers, microphones and projectors, among other equipment, were not tested in our presence to see whether or not they were functioning. Even if we had to test them, there is no regular electricity supply in Nigeria to regulate the use of these tools. The reverse is true with university libraries in South Africa, where the electricity supply is very regular in the library facilities across the country. The availability of the various ICTs mentioned and 
observed in South Africa could mean that there are policies guiding their acquisition in the libraries. Adequate funds, trained ICT and KM personnel in the operation of the tools are other major factors to consider in the university libraries.

The study also revealed that ICT tools are largely used on a daily basis in the management of information and knowledge resources and specifically with job execution in the libraries. This reiterates the applicability of the perceived usefulness that is discussed in TAM by Davis (1989). Thus, it can be noted that the willingness and decision of an individual to use available systems depend on a number of factors. One of such factors, for example, is the technical know-how, competence that is required to use the facilities and user friendliness of the technology itself. Limited use of ICTs can also be attributed to lack of ICT knowledge, skills, experience and attitudes that stem from both external and internal influences. We believe that the re-skilling and training of librarians to acquire ICT knowledge and skills is one way that helps improve the usefulness and perceived ease of use of ICTs in libraries.

\section{Accessibility of information and communication technologies for knowledge management}

It is common knowledge that a service or product may be available, but not accessible. The accessibility of ICTs for proper KM depends largely on the university libraries for quick and free access. It was revealed that the UI accessibility was far better than those in the sample, followed by the three universities in South Africa. These had a relative mean accessibility rate of $87 \%$. The availability of ICTs for KM operations in UI was lower than that of South African university libraries. This again confirms that the availability of ICT tools does not automatically translate into accessibility. Accessibility was believed to be higher in South Africa than in Nigeria with respect to e-mail, text summarising and OPAC. The support of libraries with functional technological tools has great effect on the information services rendered to users and other management functions. As noted by Chao (2014:43), it enforces and improves productivity of staff during accessibility. Chao (2014:43) and Brown (2008) elaborated on the importance of information technology infrastructure and the proper configuration of the virtual computing environment. He acknowledged the need for outstanding operating systems that could provide a flexible structure for quality service delivery. Therefore, librarians should strive in order to have access to diverse information resources and services through the aid of emerging technologies in their university libraries.

\section{Effectiveness of information and communication technologies for knowledge management}

Findings from the questionnaire revealed that the most effective ICTs used for KM differ across all sampled university libraries in the two countries. This includes the Internet, e-mail, file sharing and text summarising. The UI in Nigeria appeared to have the most effective tools, followed by DUT in South African university libraries. It can be noted that the effectiveness of ICTs for KM depends on the knowledge, skills and experience the librarians possess for the services they offer. Recent trends in research and development of library and information services have shown that the effectiveness of technological tools in managing resources and improving staff productivity in organisations is very crucial (Chaubey 2015; Omotayo 2015). According to Chisenga (2006:9), the effectiveness of ICTs for KM has allowed library users to access information resources globally without necessarily visiting the physical library building. It is acknowledged that the Internet and the mobile phone have predominantly contributed to the effectiveness of ICT for $\mathrm{KM}$, and the 'perceived ease of use and usefulness' of the tools, again, play a key role.

\section{To what extent are librarians utilising information and communication technologies to support knowledge management in academic libraries in Nigeria and South Africa?}

Result for this research question is presented in Table 3. Findings from the questionnaire revealed that the most frequently used ICT tools consisted mainly of software that performs highly specialised tasks and requires high expertise. Computers, scanners, printers, CD-ROMs, monitors, search engines and information retrieval tools and its peripherals were most commonly used. The simulation tools, artificial intelligence, decision support systems, data mining and

TABLE 3: Extent to which librarian utilise information and communication technologies for the support of knowledge management (\%).

\begin{tabular}{|c|c|c|c|c|c|c|c|}
\hline $\begin{array}{l}\text { Extent of librarian utilisation of information and communication } \\
\text { technologies for knowledge management }\end{array}$ & UI & FUT & DSU & UZ & UKZN & DUT & Ave $\%$ \\
\hline Rendering information and administrative services & 86 & 75 & 71 & 94 & 71 & 72 & 79 \\
\hline Support for research and curriculum development process & 76 & 96 & 90 & 96 & 94 & 78 & 89 \\
\hline Formulation of policies and strategic planning & 66 & 93 & 93 & 89 & 84 & 68 & 80 \\
\hline Teaching and learning processes for newly registered users & 91 & 86 & 90 & 82 & 93 & 78 & 84 \\
\hline Problem-solving and decision-making & 76 & 76 & 87 & 82 & 97 & 77 & 85 \\
\hline Minutes in staff management meetings & 85 & 75 & 84 & 67 & 82 & 81 & 77 \\
\hline In-service development and training for support staff & 92 & 100 & 86 & 77 & 99 & 92 & 89 \\
\hline Transferring existing knowledge into other parts of the organisation & 99 & 96 & 92 & 82 & 92 & 94 & 89 \\
\hline Generating new knowledge and filtering old knowledge & 95 & 86 & 99 & 82 & 80 & 92 & 85 \\
\hline Accessing valuable knowledge from external sources & 75 & 76 & 86 & 83 & 86 & 66 & 78 \\
\hline Storing content documents in databases & 76 & 86 & 93 & 99 & 87 & 72 & 86 \\
\hline
\end{tabular}

UI, University of Ibadan; FUT, Federal University of Technology; DSU, Delta State University; UZ, University of Zululand; UKZN, University of KwaZulu-Natal; DUT, Durban University of Technology; Ave, Average. 
online analytic tools were the least used across the two countries' libraries. At the university libraries' level, the greatest use of ICT tools was at UI, followed by UZ. It was further revealed that the low application of ICT hardware can be attributed to challenges relating to funding, whereas low utilisation of specialised software can be traced back to lack of knowledge of ICT tools. Findings from the interviews revealed that procurement, processing, access, planning, metadata, policy design, community service, abstracting and indexing services, photocopying, scanning and digitisation of documents, networking, preservation, training of staff and users, lending and inter-library loan services, and dissemination of information and knowledge to meet users' needs were feasible through diverse set of the ICT tools. These were extensively used in the library environment on daily basis. The operations or functions that lead to the use of these set of tools can be classified into specific and general work operations.

Ofori-Dwumfuo and Kommey (2013:92) agree that ICTs now include new devices such as cell phones, tape recorders and magnetic devices to improve knowledge collection, storage and exchange on a scale that was not possible in the past. Users now place great emphasis on web 2.0 technologies (e.g. WhatsApp, Facebook, YouTube, Social networking, Wikis, Wikipedia, Twitter, skype, instant messaging, blogs and Myspace) and web-based resources that satisfy their information needs 'at the touch of a button', as also noted by Ward (2001) referring to Internet and www.

\section{Comparing the use of information and communication technologies for knowledge management in academic libraries}

The surveyed librarians and interviewed informants revealed that there were lots of differences with the use of ICT tools used to manage knowledge in their various libraries. It was established that the use of ICT for KM at UI was relatively higher than that occurred at UZ, UKZN and DUT that was moderate. DSU library was the lowest followed by FUT. It can be expected that the availability of these services rendered by librarians results in the frequent use of the tools. Notably, the South African university librarians attest to use the tools for KM most when compared with the Nigerian sample. The libraries converged in use of text summarising and text messages. The widest gaps between the samples in the two countries were in file sharing and OPACs. The correlation coefficient of these two variables was weak but significant. File sharing appears to occur between university libraries and persons outside the university as it correlates more with the Internet than with the intranet. Raju (2014) also observed that different ICT tools, in particular social media, mobile devices, tablets and its peripherals, and library virtual space, have influenced the expansion of collections and services rendered to users by Library and Information Science (LIS) professionals. A study by Kalusopa (2005:422) also agrees that the provision of current and precise information that is systematically collected and repackaged opens up new sources and services for users in present-day library operations.
Extent to which librarians utilise information and communication technologies to support knowledge management

The utilisation of the ICT tools cannot be quantified if we have to do so. The essence is that there is no time that its use has not been of immerse value to man and specifically in management function of library operations. The extent to which the ICTs are utilised cut across the followings reasons: (1) rendering information and administrative services to users; (2) support for research and curriculum development processes; (3) formulation of policies and strategic planning; (4) teaching and learning processes; (5) registration of new users; (6) problem-solving and decision-making; (7) inservice development and training; (8) supporting staff in transferring existing knowledge to other parts of the organisation; and (9) generating new knowledge and filtering old ones. The uses occurred in all the sampled libraries with DSU, UZ, UKZN and UI leading the pack.

\section{Information sources that guide librarians in the use of information and communication technologies for knowledge management}

The librarians attest to different or multiplicity of sources that support the use of ICTs for KM. The most sourced resources are library catalogues, theses and dissertations, reviews or journal articles and Internet sources. It was further revealed that all the university libraries across the two countries preferred one information source over another based on the information needs of the users and libraries. The choice of particular information or source is influenced by the purpose of searching for such information and on the information needs of the users. Fillip and Foote (2007:v) acknowledge that information access has become more appreciated since the rise of the Internet and digital technologies. This has helped to create and foster the sharing of knowledge with peers in the library environment. Studies by Wachira and Onyancha (2012) and Declan (2011) assert that formal and informal sources of information and human resources are now used to meet diverse users' information needs.

\section{What are the challenges faced in the use of information and communication technologies to support knowledge management in academic libraries in Nigeria and South Africa?}

The most voiced challenges highlighted in Table 4 include inadequate funding, lack of motivation and lack of infrastructure. The least cited challenges include moving to other professions, language barriers and the ability to work independently. The challenges were most pronounced at DUT and least pronounced at FUT. It was established that inadequate funding has a negative impact on infrastructural development and capacity building. We note that some of these problems result from context (environment), cultural background, lack of maintenance of available infrastructure and the misplacement of organisational priority.

The results suggested that on average, university libraries in South Africa were experiencing fewer challenges than in 
TABLE 4: Challenges faced in the use of information and communication technologies for the support of knowledge management (\%).

\begin{tabular}{|c|c|c|c|c|c|c|c|}
\hline $\begin{array}{l}\text { Challenges faced in the use of information and } \\
\text { communication technologies }\end{array}$ & UI & FUT & DSU & UZ & UKZN & DUT & Ave $\%$ \\
\hline Lack of motivation & 90 & 100 & 91 & 89 & 89 & 100 & 93 \\
\hline Lack of trust & 86 & 88 & 81 & 89 & 79 & 83 & 84 \\
\hline Inadequate funds & 93 & 100 & 94 & 89 & 96 & 89 & 94 \\
\hline Knowledge of subject expert & 83 & 94 & 75 & 78 & 86 & 83 & 83 \\
\hline Drift to other professions & 72 & 56 & 66 & 67 & 75 & 67 & 67 \\
\hline Lack of infrastructure & 93 & 94 & 100 & 89 & 93 & 83 & 92 \\
\hline Lack of organisational growth & 79 & 81 & 78 & 89 & 86 & 78 & 82 \\
\hline Lack of self-development & 90 & 94 & 91 & 89 & 82 & 94 & 90 \\
\hline Inaccessibility of library resources & 86 & 69 & 91 & 100 & 89 & 89 & 87 \\
\hline Inability to cope with changes & 93 & 94 & 91 & 89 & 82 & 89 & 90 \\
\hline Insufficient ability to manage knowledge assets & 90 & 69 & 91 & 78 & 82 & 89 & 83 \\
\hline Unreliable Internet network & 90 & 88 & 88 & 89 & 82 & 89 & 88 \\
\hline Unreliable electricity & 90 & 100 & 97 & 89 & 75 & 89 & 90 \\
\hline Lack of current trends & 79 & 75 & 88 & 78 & 82 & 94 & 83 \\
\hline Language barrier & 79 & 63 & 59 & 78 & 71 & 89 & 73 \\
\hline Poor KM practices & 83 & 81 & 91 & 89 & 82 & 78 & 84 \\
\hline Lack of personal computer & 83 & 63 & 81 & 89 & 71 & 94 & 80 \\
\hline Costs of hardware and software & 97 & 69 & 84 & 89 & 86 & 94 & 87 \\
\hline Lack of policy implementation & 86 & 81 & 94 & 100 & 86 & 94 & 90 \\
\hline Lack of adherence to instructions & 97 & 69 & 72 & 100 & 96 & 89 & 87 \\
\hline Lack knowledge to use ICTs and web & 86 & 75 & 91 & 89 & 82 & 94 & 86 \\
\hline Lack of knowledge of library holdings & 79 & 69 & 69 & 89 & 93 & 89 & 81 \\
\hline Inability to understand users' queries & 93 & 75 & 81 & 89 & 93 & 89 & 87 \\
\hline Lack of knowledge production & 83 & 81 & 78 & 100 & 89 & 94 & 88 \\
\hline Inability to work independently & 83 & 88 & 63 & 78 & 64 & 83 & 77 \\
\hline
\end{tabular}

Inability to work independently

83

Ave, Average.

Nigeria. Inadequate funding and infrastructural challenges were more pronounced in Nigeria. Notably, the most critical challenges to address in the use of ICTs for the support of KM include lack of infrastructure, inadequate funds, unreliable electricity and unreliable Internet networks. A study by Ajuwon and Rhine (2008) determined that ICT facilities and the regular training of librarians are essential for the full support of KM in academic libraries.

Interviews with the key informants revealed that the most crucial challenges faced by Nigerian university libraries include inadequate funding, poor or old ICT facilities, and inadequate professional staff. The South African interviewees cited inadequate professional staff, lack of commitment to work and increased user needs. Evidently, inadequate professional staff is a common problem in both countries' libraries. As attested in the interview conducted was the worrisome issue of the ability of the management of libraries to act towards the eradication of these problems. Related studies by Agboh (2015), Fink and Disterer (2006), Jones, Davies and Muir (2003), and Khatibi, Thyagarajan and Seetharaman (2003) also identify the lack of government support systems, complex procedures, managerial leadership, cost benefits and needs analysis, legal issues, turnover, security and lack of human capital, among others, to be the most critical challenges in university libraries.

\section{Conclusion}

The utilisation of ICTs for KM in present-day library organisation cannot be undermined. This has brought new paradigm of how information and knowledge are repackaged for decision-making and planning. The authors noted that the availability and accessibility of ICTs for KM among the sampled university libraries were not uniform, even within one country. Infrastructural support has affected some of the university libraries to a great extent. The irregular electricity supply in Nigeria made it difficult to believe that the ICTs were really functional. The knowledge and skills for using ICT for KM were largely adequate, but varied within the libraries and librarians as well. The need for re-skilling of librarians becomes significant as it would help to bridge the gap and reduce knowledge loss in the library organisation. Relative to the Nigerian sample, the South African sampled university libraries were better equipped in using ICTs for KM in terms of availability, accessibility, services and effectiveness. Satgoor's (2015) study confirms that university libraries in South Africa are better equipped and funded for information services. It is, though, not unusual to find that most African university libraries are poorly resourced and funded (Enyia 2013; Okiy 2005; Osagie \& Orheruta 2013:195).

The challenges facing the libraries, as reported in Table 2, are numerous, with inadequate professional staff topping the list. However, irrespective of the challenges faced, libraries have devised strategies for coping and rendering services. The re-skilling of librarians through continuous education becomes feasible with the help of government or institutional support through functional policies, and funding should enable the better integration of ICT with KM in the libraries 
where this has not occurred. Based on the findings, there are sound lessons to be learnt by the university libraries from both countries, and a forum for doing so is urgently needed.

\section{Acknowledgements}

This study is extracted and revised from a PhD thesis produced by one of the authors (see http://uzspace.uzulu. ac.za/handle/10530/1470). The University of Zululand and Delta State University are acknowledged for the support provided towards the development and finalisation of this research work. The authors also acknowledge the support they received from reviewers towards the improvement of the quality of the article.

\section{Competing interests}

The authors declare that they have no financial or personal relationships that may have inappropriately influenced them in writing this article.

\section{Authors' contributions}

R.T.E. is the author of the $\mathrm{PhD}$ thesis from which the article was extracted, conceptualised the research idea, executed the study and jointly wrote the article. D.N.O. is the supervisor of the PhD project and with R.T.E. has jointly written the article.

\section{References}

Agboh, D.K., 2015, 'Drivers and challenges of ICT adoption by SMES in Accra metropolis, Ghana', Journal of Technology Research 6, 1-16, viewed 20 August 2015, from http://www.aabri.com/manuscripts/142044.pdf

Ajuwon, G. \& Rhine, L., 2008, 'The level of Internet access and ICT training for health information professionals in Sub-Saharan Africa', Health Information and Libraries Journal 25, 175-185. https://doi.org/10.1111/j.1471-1842.2007.00758.x

Al-Qeisi, K.I., 2009, 'Analysing the use of UTAUT model in explaining an online behaviour: Internet banking adoption', PhD thesis, submitted at the Department of Marketing and Branding, Brunel University.

Anunobi, C.V., Anyanwu, O.P., Oga, M. \& Benard, I.I., 2011, 'The adoption of ICT for library and information services', Nigerian Libraries 44(1), 89-104.

Beesley, L.G.A. \& Cooper, G., 2008, 'Defining knowledge management (KM) activities: Towards consensus', Journal of Knowledge Management 12(3), 48-62. https:// doi.org/10.1108/13673270810875859

Bhardwaj, R.K. \& Walia, P.K., 2012, 'Web based information sources and services: A case study of St. Stephen's College, University of Delhi', Library Philosophy and Practice, ISSN 1522-0222, viewed 19 January 2015, from http://www.webpages. uidaho.edu/ mbolin/bhardwaj-walia.htm

Blurton, C., 1999, 'New directions of ICT-use in education', viewed 12 July 2012 http://ehlt.flinders.edu.au/education/

Brown, S.A., 2008, 'Household technology adoption, use, and impacts: Past, present, and future', Information Systems Frontiers 10(4), 397-402. https://doi.org/10. 1007/s10796-008-9098-z

Chao, L., 2014, 'Application of infrastructure as a service in IT education', American Journal of Information Systems 2(2), 42-48.

Chaubey, A.K., 2015, 'Skill and competency require in knowledge management in libraries and information centre in current era', E-Journal of Library and Information Science 2(4), 184-210.

Chisenga, J., 2006, 'Information and communication technologies: Opportunities and challenges for national and university libraries in Eastern, Central and Southern Africa, 2006', in Standing Conference of African National and University Libraries of Eastern, Central and Southern Africa, Dar es Salaam, Tanzania, July 9-10, 2006 viewed 12 July 2012, from http://eprints.rclis.org/bitstream/10760/9579/1/ Chisenga SCANUL 2006.pdf

Dafiaghor, F.K., 2012, 'Problems and prospects of electronic resources usage in Nigerian academic libraries', Journal of Economics and International Finance 4(9), 220-225

Dalkir, K., 2011, Knowledge management in theory and practice, MIT, Cambridge, MA.

Davis, F.D., 1989, 'Perceived usefulness, perceived ease of use, and user acceptance of information technology', MIS Quarterly 13(3), 319-340. https://doi.org/10.2307/ 249008
Davis, F.D., Bagozzi, R.P. \& Warshaw, P.R., 1989, 'User acceptance of computer technology: A comparison of two theoretical models', Management Science 35(8), 982-1003. https://doi.org/10.1287/mnsc.35.8.982

Declan, W., 2011, 'Human resources: Formal vs. informal recruitment', viewed 25 April 2014, from http://www.candidatemanager.net/news/2011/04/formal-informalrecruitment.asp

Enyia, C.O., 2013, 'The management of library development funds in the Nigerian University System', Journal of Librarianship and Information Science 34(2), viewed 7 November 2014, from http://lis.sagepub.com/content/34/2/91.abstract

Evangelista, P., Esposito, E., Lauro, V. \& Raffa, M., 2010, 'The adoption of knowledge management systems in small firms', Electronic Journal of Knowledge Management 8(1), 33-42.

Fari, S.A., 2015, 'Applying social capital theory and the technology acceptance mode in information and knowledge sharing research', Inkanyiso: Journal of Humanities and Social Sciences 7(1), 19-28.

Fillip, B. \& Foote, D., 2007, 'Making the connections scaling telecentres for development', Information Application Centre, viewed 12 July 2014, from http:// connection.aed.org/pages/makingconnections.pdf

Fink, D. \& Disterer, G., 2006, 'International case study: To what extent is ICT infused into the operations of SMEs', Journal of Enterprise Information Management 19(6), 608-624. https://doi.org/10.1108/17410390610708490

Jones, P., Davies, P.B. \& Muir, E., 2003, 'E-business barriers to growth within the SME sector', Journal of Systems and Information Technology 7(1), 1-25. https://doi. org/10.1108/13287260380000771

Kalusopa, T., 2005, 'The challenges of utilizing information communication technologies (ICTs) for the small-scale farmers in Zambia', Library Hi Tech 23(3) 414-424. https://doi.org/10.1108/07378830510621810

Khatibi, A., Thyagarajan, V. \& Seetharaman, A., 2003, 'E-commerce in Malaysia: Perceived benefits and barriers', viewed 20 June 2015, from www.vikalpa.com/ pdf/articles

King, W.R. \& He, J., 2006, 'A meta-analysis of the technology acceptance model', Information and Management 43, 740-755. http://dx.doi.org/10.1016/j.im.2006.05.003

Lee, Y., Kozar, K.A. \& Larsen, K.R.T., 2003, 'The technology acceptance model: Past, present, and future', Communications of the Association for Information Systems 12, Article 50, viewed 17 November 2014, from http://aisel.aisnet.org/cais/vol12/iss1/50

Martin, L., 2015, Innovative work practices, ICT use and employees' motivations, Luxembourg Institute of Socio-Economic Research (LISER), Luxembourg, viewed 23 November 2014, from http://www.liser.lu

Minonne, C., 2007, 'Towards an integrative-approach for managing implicit and explicit knowledge: An exploratory study in Switzerland', viewed 19 August 2012, from http://ebookbrowse.com/article-clemente-minonne-eckm-2007-v-1-2-pdf-d 144113461

Nonaka, I., 1994, 'A dynamic theory of organizational knowledge creation', Organizational Science 5(1), 14-37. https://doi.org/10.1287/orsc.5.1.14

Nonaka, I., Ichijo, K. \& Von Krogh, G., 2004, Enabling knowledge creation: How to unlock the mystery of tacit knowledge and release the power of innovation. Oxford University Press, New York.

Nonaka, I. \& Krogh, G.V., 2009, 'Tacit knowledge and knowledge conversion: Controversy and advancement in organizational knowledge creation theory', Organization Science 20(3), 635-652, viewed 12 June 2014, from https://ai.wu. ac.at/ kaiser/literatur/nonaka-knowledge-conversion.pdf

Nonaka, I., Umemoto, K. \& Senoo, D., 1996, 'From information processing to knowledge creation: A paradigm shift in business management', Technology in Society 18(2), 203-218. https://doi.org/10.1016/0160-791X(96)00001-2

Ofori-Dwumfuo, G.O. \& Kommey, R.E., 2013, 'Utilization of ICT in knowledge management at the Ghana Volta River Authority', Current Research Journal of Social Sciences 5(3), 91-102, viewed 28 May 2013, from http://www.maxwellsci. com/print/crjss/v5-91-102.pdf

Okiy, R.B., 2005, 'Funding Nigerian libraries in the 21st century: Will funding from alternative sources suffice', The Bottom Line: Managing Library Finances 18(2), 71-77. https://doi.org/10.1108/08880450510597514

Omotayo, F.O., 2015, 'Knowledge management as an important tool in organisational management: A review of literature', Library Philosophy and Practice (e-journal), Paper 1238, viewed 16 January 2016, from http://digitalcommons.unl.edu/cgi/ viewcontent.cgi?article $=3330 \&$ context=libphilprac

Online Computer Library Center, OCLC, 2002, 'Academic librarians can influence students' web based information choices: OCLC white paper on the information habits of college students', viewed 22 December 2015, from http://www.oclc.org/ downloads/community/informationhabits.pdf

Osagie, R. \& Orheruata, M.U., 2013, 'Budgeting and funding of the library at the University of Benin, Edo State, Nigeria', Education 134(2), Winter 2013, viewed 7 November 2014, from https://www.questia.com/library/journal/1G1-356352098/ budgeting-and-funding-of-the-library-at-the-university

Raju, J., 2014, 'Knowledge and skills for the digital era academic library', The Journal of Academic Librarianship 40, 163-170. https://doi.org/10.1016/j.acalib.2014.02.007

Ramayah, T., 2006, 'Interface characteristics, perceived ease of use and intention to use an online library in Malaysia', Information Development 22(2), 123-133. https://doi.org/10.1177/0266666906065575

Ridwan, S.M., 2015, 'Application of information and communication technology in management of information resources and services in Kaduna State Tertiary Institutions' Libraries, Kaduna-Nigeria', European Scientific Journal 1, 25-32. ISSN: 1857-7881. 
Rowley, J., 2003, 'Knowledge management - The new librarianship: From custodians of history to gatekeepers to the future', Library Management 24(8), 433-440. https://doi.org/10.1108/01435120310501112

Satgoor, U., 2015, 'Celebrating libraries in 20 years of democracy: An overview of library and information services in South Africa', International Federation of Library Association 41(2), 97-111. https://doi.org/10.1177/0340035215585100

Skyrme, D., 1997, Knowledge management: Approaches and policies, viewed 17 July 2011, from http://www.skyrme.cm/pubs/deedskm.doc

Taiwo, A.A. \& Downe, A.G., 2013, 'The theory of user acceptance and use of technology (UTAUT): A meta-analytic review of empirical findings', Journal of Theoretical and Applied Information Technology 49(1), 48-58.

UNESCO, 2002, Information and communication in education: A curriculum for schools and programme of teachers' development, UNESCO, Paris.

Venkatesh, V., 2000, 'Determinants of perceived ease of use: Integrating control, intrinsic motivation, and emotion into the technology acceptance model', Information Systems Research 11, 342-365. https://doi.org/10.1287/isre.11.4. 342.11872

Venkatesh, V. \& Bala, H., 2008, 'TAM 3: Advancing the technology acceptance model with a focus on interventions', Manuscript in-preparation, viewed 6 August 2014 from http://www.vvenkatesh.com/it/organizations/theoretical_models.asp
Venkatesh, V., Brown, S.A., Maruping, L.M. \& Bala, H., 2008, 'Predicting different conceptualizations of system use: The competing roles of behavioural intention,
facilitating conditions, and behavioural expectation', MIS Quarterly 32(3), 483-502.

Venkatesh, V. \& Davis, F.D., 2000, 'A theoretical extension of the technology acceptance model: Four longitudinal field studies', Management Science 46(2), 186-204. https://doi.org/10.1287/mnsc.46.2.186.11926

Venkatesh, V., Morris, M., Davis, G. \& Davis, F.D., 2003, 'User acceptance of information technology: Toward a unified view', MIS Quarterly 27(3), 425-478, viewed 18 October 2014, from http://www.cis.gsu.edu/ ghubona/info790/VenkEtAIMIQ03. pdf

Venkatesh, V., Thong, J.Y.L. \& Xu, X., 2012, 'Consumer acceptance and use of information technology: Extending the unified theory of acceptance and use of technology', MIS Quarterly 36, 157-178.

Wachira, M.N. \& Onyancha, O.B., 2012, 'Serving remote users in selected public university libraries in Kenya: discussions with section heads', Paper presented at the SCECSAL XXth Conference hosted by KLA, the Laico Regency Hotel, Nairobi, Kenya. Published in Pretoria, June 4-8, 2012.

Ward, M., 2001, 'A survey of engineers in their information world', Journal of Librarianship and Information Science 33(4), 168-176. https://doi.org/10.1177/
096100060103300402 